\title{
The impact of the metal interface on the stability and quality of a therapeutic fusion protein
}

Adrian P. Defante1, Cavan K. Kalonia², Emma Keegan², Steven M. Bishop², Hasige A. Satish², Steven D. Hudson ${ }^{1}$ and Paul V. Santacroce ${ }^{2}$

${ }^{1}$ Material Measurement Laboratory, National Institute of Standards and Technology (NIST), Gaithersburg, Maryland 20899 United States

${ }^{2}$ Dosage Form Design and Development, AstraZeneca., Gaithersburg, Maryland 20878 United States

Supporting Information

SI1: Formulation Characterization for Different Lots

\begin{tabular}{|c|c|c|c|}
\hline Test & Lot A DP & Lot B DP & Lot A DS \\
\hline Total Protein $(\mathrm{mg} / \mathrm{mL})$ & 49.2 & 50.8 & 49.8 \\
\hline $\mathrm{pH}$ & 6.9 & 6.9 & 6.9 \\
\hline $\begin{array}{c}\text { Size exclusion } \\
\text { Chromatography (\% } \\
\text { monomer concentration) }\end{array}$ & $98.5 ; 1.4 ; 0.1$ & $97.9 ; 1.9 ; 0.2$ & $98.2 ; 1.7 ; 0.1$ \\
\hline $\begin{array}{c}\text { Non-reducing Gel } \\
\text { Electrophoresis (\% } \\
\text { monomer concentration) }\end{array}$ & 98.6 & 100 & 97.7 \\
\hline
\end{tabular}

Drug Substance (DS), Drug Product (DP)

Figure SI2: Particle Analysis of Sub visible particles (SVP) 
a
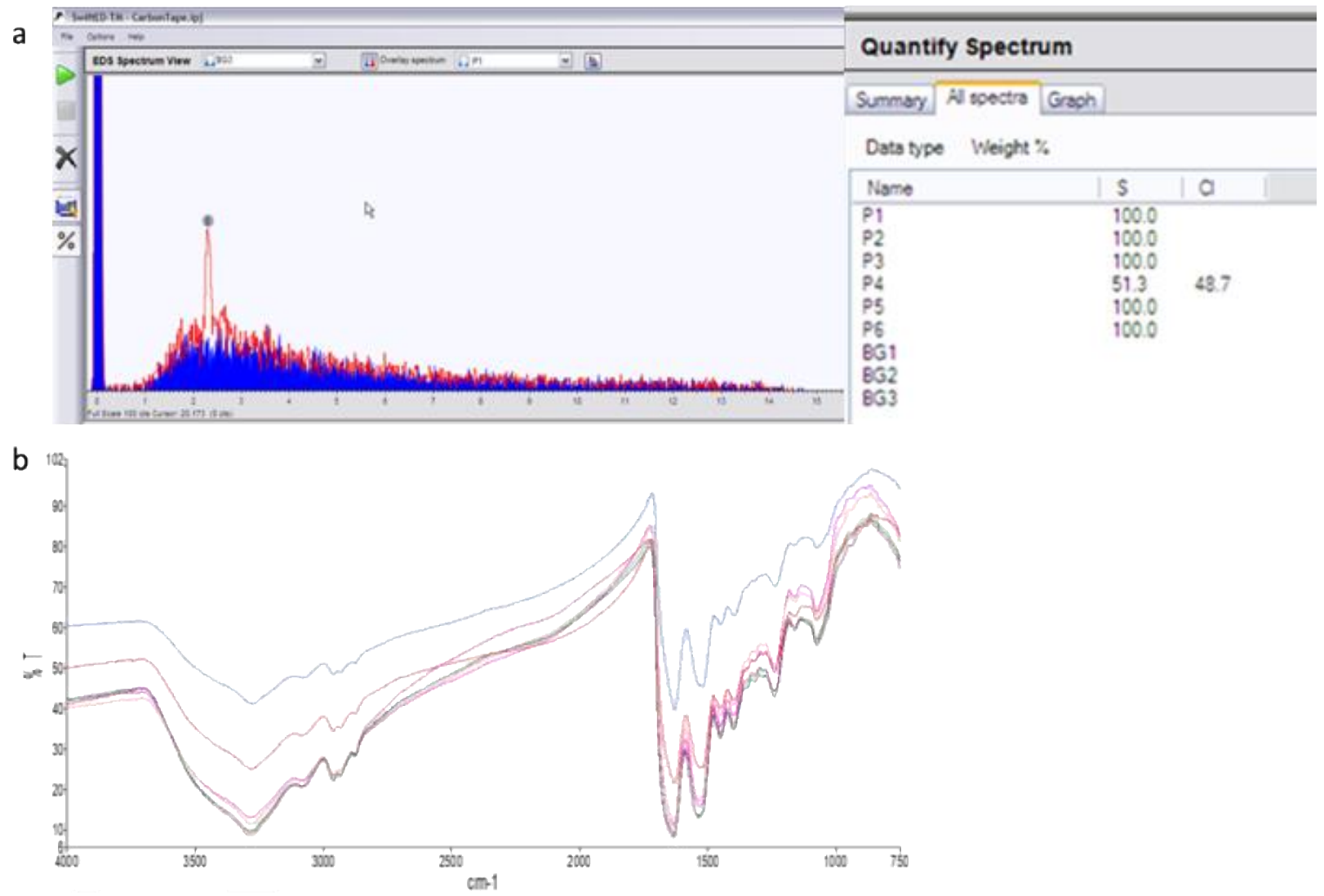

Figure S12: a.) Scanning electron microscopy elemental analysis and b.) Fourier Transform Infrared spectroscopy of SVPs indicating the absence of metal particulates and composition of organic proteinaceous material in solution. 

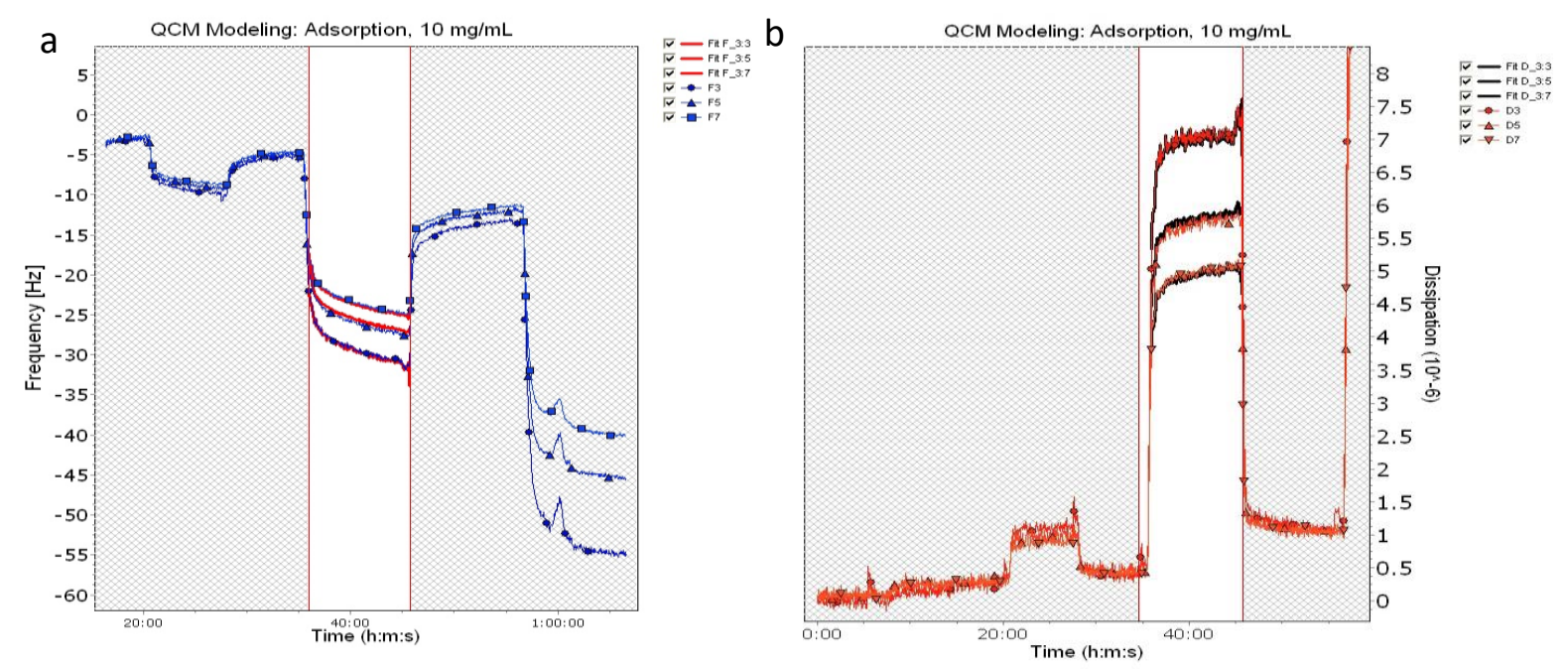

Figure SI3: A 2-layer Voigt model was used to model the viscoelastic characteristics for separated overtones in a.) frequency and b.) dissipation. The dotted lines are the measured data and the solid dark lines are the modeled fits.

The results were fit using a 2-layer (primary and secondary layer) model where a power law was used to model the magnitude of the complex modulus and phase angle. The film properties of viscosity and elasticity of the primary layer were estimated using a 1-layer Voigt model for data that followed the washed period for each concentration.

Table 2: Example of Quartz crystal microbalance with dissipation monitoring (QCM-D) fitting parameters of the 2-layer model for different concentrations. Details of QCM-modeling can be found elsewhere ${ }^{1-3}$. 


\begin{tabular}{|c|c|c|c|c|c|}
\hline Layer 1 & Units & $10 \mathrm{mg} / \mathrm{mL}$ & $25 \mathrm{mg} / \mathrm{mL}$ & $50 \mathrm{mg} / \mathrm{mL}$ & $10 \mathrm{mg} / \mathrm{mL}$ \\
\hline Fluid Density & $\mathrm{kg} / \mathrm{m}^{\wedge} 3$ & 1003 & 1007 & 1015 & 1033 \\
\hline Fluid Viscosity & $\mathrm{kg} / \mathrm{ms}$ & 0.00167 & 0.00237 & 0.00272 & 0.002865 \\
\hline Layer Density & $\mathrm{kg} / \mathrm{m}^{\wedge} 3$ & 1126 & 1126 & 1126 & 1126 \\
\hline Layer Viscosity & $\mathrm{kg} / \mathrm{ms}$ & 0.0048 & 0.0062 & 0.00726 & 0.0068 \\
\hline Layer Shear & $\mathrm{Pa}$ & $7.60 \mathrm{E}+05$ & $1.48 \mathrm{E}+06$ & $1.85 \mathrm{E}+05$ & $1.75 \mathrm{E}+06$ \\
\hline Mass & $\mathrm{ng} / \mathrm{cm}^{\wedge} 2$ & 284 & 358 & 485 & 536 \\
\hline & & & & & \\
\hline Layer 2 & & & & & \\
\hline Layer Viscosity & $\mathrm{kg} / \mathrm{ms}$ & $2.05 \mathrm{E}-03$ & $2.94 \mathrm{E}-03$ & $2.15 \mathrm{E}+05$ & $3.20 \mathrm{E}-03$ \\
\hline Layer Shear & $\mathrm{Pa}$ & $4.80 \mathrm{E}+04$ & $1.80 \mathrm{E}+05$ & $2.70 \mathrm{E}+05$ & $2.15 \mathrm{E}+05$ \\
\hline Mass & $\mathrm{ng} / \mathrm{cm}^{\wedge} 2$ & 980 & 1320 & 1875 & 6700 \\
\hline Freq_visc & & 0.00 & -0.03 & 0.03 & 0.03 \\
\hline Freq_shear & & 0.39 & 0.20 & 0.29 & 0.40 \\
\hline
\end{tabular}

SI4: Structure of fusion protein adsorbed to stainless steel (SS) determined from modeled neutron reflectivity data. Highlighted cells are material constants used for fitting purposes. 


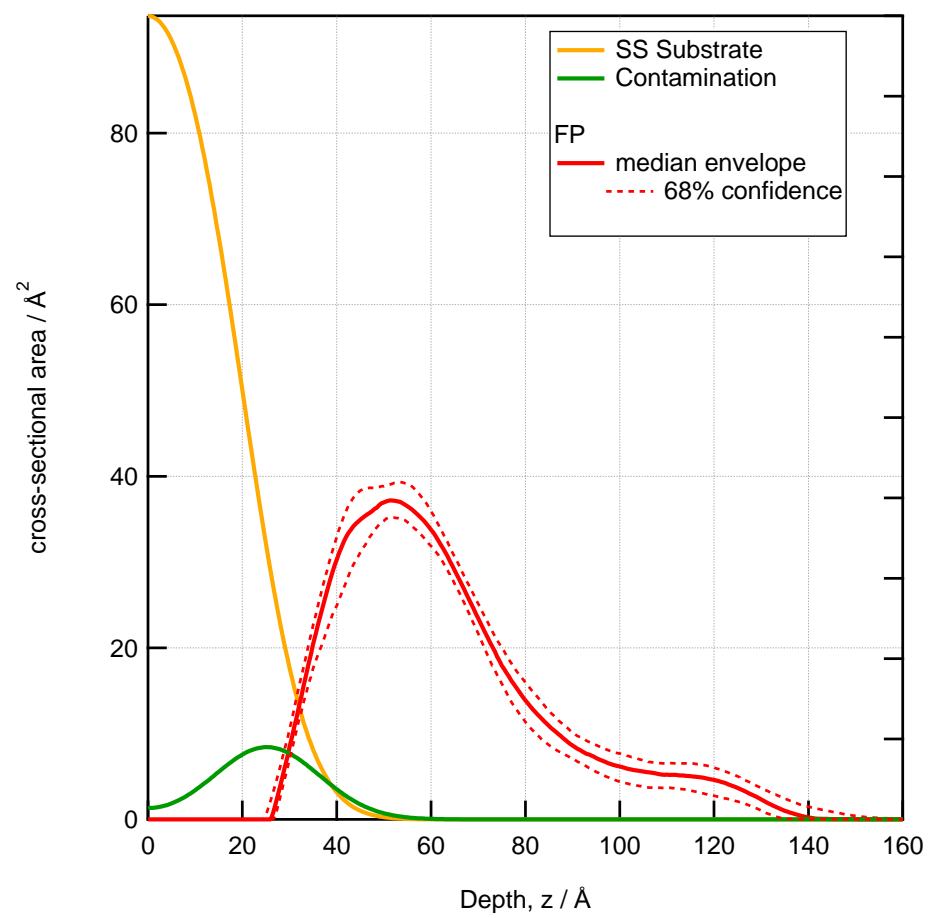

Figure SI4: The solid red trace represents the structure of the adsorbed fusion protein layer with the dashed red traces representing the $68 \%$ confidence interval determined through Monte Carlo simulation. The orange trace represents the edge of the stainless-steel with the gradual transition representing its surface roughness. The green trace represents contamination or contribution from excipient adsorption.

The MAGIK off-specular reflectometer at the National Institute of Standards and Technology Center for Neutron Research (NCNR) was used for neutron reflectometry measurements with a standard flow cell configuration ${ }^{4-6}$. The flow cell was assembled using a silicon wafer sputter coated using a $316 \mathrm{~L}$ stainless steel target as described previously ${ }^{4}$. Specular reflection data was collected over a momentum transfer $\left(Q_{z}\right)$ range of $0.008 \dot{A}^{-1}$ to $0.250 \dot{A}^{-1}$ with increased counting times at higher $Q_{z}$ values.

The reflectivity profile of the stainless-steel substrate was measured in the presence of $\mathrm{H}_{2} \mathrm{O}$ formulation buffer and $\mathrm{D}_{2} \mathrm{O}$ formulation buffer to determine the structure and roughness of the interface as well as any contribution of contamination/adsorption of excipients. $10 \mathrm{mg} / \mathrm{ml}$ fusion protein was then injected and measured using $\mathrm{H}_{2} \mathrm{O}$ and $\mathrm{D}_{2} \mathrm{O}$ to modulate the contrast of the bulk solution. Measurements were collected for approximately $6.5 \mathrm{~h}$. Data reduction and analysis was performed using the methods described previously ${ }^{4}$.

\section{References}


1. Vogt BD, Lin EK, Wu W-L, White CC. Effect of Film Thickness on the Validity of the Sauerbrey Equation for Hydrated Polyelectrolyte Films. J Phys Chem B. 2004;108(34):12685-12690.

2. Sadman K, Wiener CG, Weiss RA, White CC, Shull KR, Vogt BD. Quantitative Rheometry of Thin Soft Materials Using the Quartz Crystal Microbalance with Dissipation. Anal Chem. 2018;90(6):4079-4088. doi:10.1021/acs.analchem.7b05423

3. Rodahl M, Hook F, Kasemo B. QCM Operation in Liquids: An Explanation of Measured Variations in Frequency and Q Factor with Liquid Conductivity.; 1997. doi:10.1021/ac951203m

4. Kalonia CK, Heinrich F, Curtis JE, Raman S, Miller MA, Hudson SD. Protein Adsorption and Layer Formation at the Stainless Steel-Solution Interface Mediates Shear-Induced Particle Formation for an IgG1 Monoclonal Antibody. Mol Pharm. 2018;15(3):1319-1331. doi:10.1021/acs.molpharmaceut.7b01127

5. Dura JA, Pierce DJ, Majkrzak CF, et al. AND/R: Advanced neutron diffractometer/reflectometer for investigation of thin films and multilayers for the life sciences. Rev Sci Instrum. 2006;77(7):74301. doi:10.1063/1.2219744

6. Kirby BJ, Kienzle PA, Maranville BB, et al. Phase-sensitive specular neutron reflectometry for imaging the nanometer scale composition depth profile of thin-film materials. Curr Opin Colloid Interface Sci. 2012;17(1):44-53.

doi:10.1016/j.cocis.2011.11.001 